\title{
Serviceability limit state related to excessive lateral deformations to account for infill walls in the structural model
}

\section{Estado limite de serviço de deformações horizontais excessivas com a consideração das alvenarias de preenchimento no modelo estrutural}
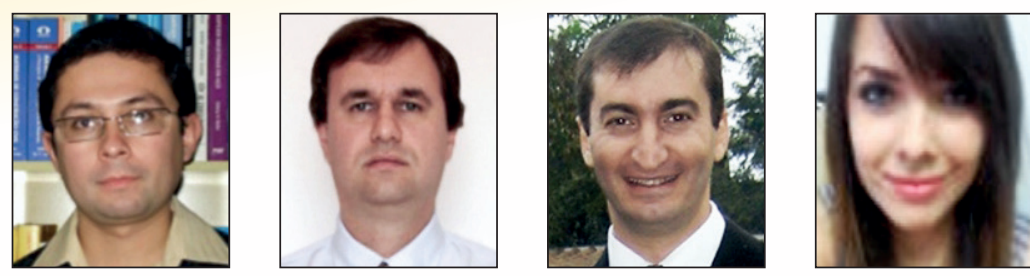

G. M. S. ALVA a alva_gerson@yahoo.com.br

\section{J. KAMINSKI JR a} jkj@ufsm.br

G. MOHAMAD a gihad.civil@gmail.com

L. R. SILVA liriane.reis@gmail.com

\begin{abstract}
Brazilian Codes NBR 6118 and NBR 15575 provide practical values for interstory drift limits applied to conventional modeling in order to prevent negative effects in masonry infill walls caused by excessive lateral deformability, however these codes do not account for infill walls in the structural model. The inclusion of infill walls in the proposed model allows for a quantitative evaluation of structural stresses in these walls and an assessment of cracking in these elements (sliding shear diagonal tension and diagonal compression cracking).

This paper presents the results of simulations of single-story one-bay infilled R/C frames. The main objective is to show how to check the serviceability limit states under lateral loads when the infill walls are included in the modeling. The results of numerical simulations allowed for an evaluation of stresses and the probable cracking pattern in infill walls. The results also allowed an identification of some advantages and limitations of the NBR 6118 practical procedure based on interstory drift limits.
\end{abstract}

Keywords: infilled frames, masonry infill walls, diagonal strut model, finite element method, serviceability limit states.

\section{Resumo}

Para evitar efeitos negativos em walls de vedação produzidos pela deformabilidade horizontal excessiva, a NBR 6118 e a NBR 15575 apresentam valores práticos de limites de deslocamentos horizontais aplicados à modelagem convencional (sem a consideração das walls de preenchimento no modelo estrutural). Entretanto, a inclusão das walls no modelo permite a avaliação quantitativa das tensões solicitantes nas alvenarias de preenchimento e a avaliação da ocorrência de fissuras nas mesmas (por cisalhamento, tração diagonal ou compressão diagonal).

Neste trabalho são apresentados resultados de simulações numéricas de quadros de concreto armado considerando a presença da alvenaria de preenchimento. O objetivo principal do trabalho é demonstrar como pode ser realizada a verificação do estado limite de serviço produzido por ações horizontais quando as walls são incluídas na modelagem. Os resultados das simulações permitiram a avaliação das tensões solicitantes e do provável tipo de fissuração nas alvenarias. Os resultados também permitiram identificar algumas vantagens e limitações do procedimento prático da NBR 6118 em termos de deslocamentos limites.

Palavras-chave: pórticos preenchidos, alvenarias de preenchimento, modelo de diagonal equivalente, método dos elementos finitos, estados limites de serviço. 


\section{Introduction}

Masonry infill walls in building frame structures are normally considered only as gravity loads applied to the main structure. In other words, the stiffness of these walls is overlooked in models of structural analysis. When fixed to the concrete frame structure, infill walls act as resistant elements to lateral loads of the building. However, it is not a current design practice in Brazil to consider masonry panels in the structural model for verifying Limit States of the structure.

There are few Brazilian studies on the structural behavior of masonry-infilled frames subjected to lateral loads. Alvarenga [1] carried out a theoretical and experimental study of steel frames with concrete masonry infills, while Santos [2], Tanaka [3] and Madia [4] focused on numerical simulations in concrete buildings.

On the other hand, there is an extensive international literature on the behavior of concrete and steel framed structures with masonry infill walls. Research in this area began to draw interest more than four decades ago, much of it focusing on analyses to respond to seismic loads. Briefly, three types of research contributions related to this subject are described below.

The first contribution is related to macromodeling research, which investigates the utilization and improvement of diagonal-strut models. A number of important studies have been published since the 1970s. Relevant studies among the more recent of these include, Asteris et al. [5], Chrysostomou and Asteris [6], El-Dakhakhni et al. [7], Amato et al. [8], Doudoumis [9], Crisafulli and Carr, [10] and Uva et al. [11]. The second line of research is related to utilization and improvement of micromodeling, in which the structure and masonry are modeled with plane or spatial elements via the finite element method, including the case of openings in the walls. Some of the more recent relevant studies include Doudoumis [12], Mondal and Jain [13], Asteris [14], Ghosh and ADSM [15], Mohyeddin et al. [16], Stavidris and Shing [17], Baloevic et al. [18] and Koutromanos et al. [19]. The third research contribution is comprised of a vast number of specialized publications focusing on experimental investigations. Among these, some noteworthy studies include those of Mehrabi et al. [20], Durrani and Haider [21], Flanagan and Bennett [22], Al-Chaar et al. [23], Asteris et al. [24], Tasnimi and Mohebkhah [25] and Liu and Manesh [26].

According to FEMA 306 [27], FEMA 274 [28] and FEMA 356 [29] guidelines, there are specific detailed procedures for analyzing concrete and steel frames with masonry infill walls. Chapter 8 of FEMA 306 [27] summarizes the main studies on the topic and presents equations for obtaining equivalent strut width for panels without openings and for obtaining strength capacity of the equivalent diagonal strut with regard to possible failure modes. These guidelines have been widely cited in related international studies over the last 15 years.

The Brazilian norms NBR 6118 [30] and NBR 15575 [31] provide interstory drift limits under service conditions for preventing negative effects on seals produced by excessive interstory drift ratio. These limits are practical values to be applied in conventional modeling (without accounting for infill walls as resistant elements) and are a simple way to minimize lateral deformability of the structure, regardless of the mechanical characteristics of the wall.

Evidently, the above-mentioned verification does not allow a quantitative evaluation of stresses in the masonry panels, nor does it account for geometric influences (dimensions, openings) or me- chanical characteristics of the walls. This evaluation can only be performed if the stiffness of the masonry panels is included in the structural model. With an assessment of stresses in the masonry panels, it is possible to examine the occurrence of possible failure modes (cracking) in walls subjected to lateral loads: by shear, by diagonal tension or by diagonal compression.

The main objective of this study is to demonstrate a way of verifying the service limit state produced by lateral loads when infill walls are included in the structural model. Numerical examples were carried out, using the equivalent diagonal strut method (DSM) and a

\section{Table 1 - Analytical equations for obtaining the equivalent strut width}

\begin{tabular}{|c|c|}
\hline Authors & Equation \\
\hline Mainstone (32) & $a=0,175 \cdot\left(\lambda_{H}\right)^{-0,4} \cdot D$ \\
\hline Hendry (34) & $\begin{array}{c}a=\frac{\sqrt{\alpha_{p}{ }^{2}+\alpha_{v}{ }^{2}}}{2} \\
\alpha_{p}=\frac{\pi}{2 . \lambda} \\
\alpha_{v}=\frac{\pi}{2 . \lambda_{v}} \\
\alpha_{p}=\text { contact length between column } \\
\text { and masonry wall; } \\
\alpha_{v}=\text { contact length between beam and } \\
\text { masonry wall. }\end{array}$ \\
\hline $\begin{array}{l}\text { Liauw e } \\
\text { Kwan (35) }\end{array}$ & $\mathrm{a}=\frac{0,95 \cdot \operatorname{sen}(2 \theta)}{2 \sqrt{\lambda_{\mathrm{H}}}} \cdot \mathrm{D}$ \\
\hline $\begin{array}{c}\text { Decanini } \\
\text { e Fantin (36) }\end{array}$ & $\begin{array}{cc}\begin{array}{c}\text { Uncracked panels: } \\
\lambda_{H} \leq 7,85:\end{array} & \begin{array}{c}\text { Uncracked panels: } \\
\lambda_{H} \leq 7,85:\end{array} \\
\mathrm{a}=\left(\begin{array}{c}\left.0,085+\frac{0,748}{\lambda_{H}}\right) \cdot D \\
\lambda_{H}>7,85:\end{array}\right. & \mathrm{a}=\left(\begin{array}{c}\left.0,010+\frac{0,707}{\lambda_{H}}\right) \cdot D \\
\lambda_{H}>7,85:\end{array}\right. \\
\mathrm{a}=\left(0,130+\frac{0,393}{\lambda_{H}}\right) \cdot \mathrm{D} & \mathrm{a}=\left(0,040+\frac{0,470}{\lambda_{H}}\right) \cdot D\end{array}$ \\
\hline $\begin{array}{c}\text { Paulay e } \\
\text { Priestley (37) }\end{array}$ & $a=\frac{D}{4}$ \\
\hline $\begin{array}{l}\text { Durrani e } \\
\text { Luo (38) }\end{array}$ & $\begin{array}{c}a=\gamma \cdot \operatorname{sen}(2 \theta) \cdot D \\
\gamma=0,32 \cdot \sqrt{\operatorname{sen}(2 \theta)} \cdot\left(\frac{H^{4} \cdot E \cdot t}{m \cdot E_{p} J_{p} \cdot h}\right)^{-0,1} \\
m=6 \cdot\left(1+\frac{6 \cdot E_{v} I_{v} \cdot H}{\pi \cdot E_{p} \cdot I_{p} \cdot L}\right) \\
E_{v}=\text { elasticity modulus of the beam; } \\
I_{v}=\text { second moment of area of the beam. }\end{array}$ \\
\hline $\begin{array}{l}\text { Chrysostomou } \\
\text { e Asteris (6) }\end{array}$ & $a=0,270 \cdot\left(\lambda_{H}\right)^{-0,4} \cdot D$ \\
\hline
\end{tabular}


model that employs the finite element method (FEM). The comparison between acting stresses and strength capacity of the walls allowed to make inferences with regard to the integrity of the walls in the face of possible failure modes (cracking) and evaluate the appropriateness of the practical drift limit values of the NBR 6118 [30] for conventional modeling. FEMA 306 guidelines [27] were used to calculate equivalent strut width and masonry strength parameters.

\section{Evaluation of stiffness and strength capacity of masonry panels}

\subsection{Diagonal strut model}

The most widely used model for simulating the contribution of masonry panels to the stiffness of framed structures under lateral loads is the equivalent strut model, which entails the introduction of pin-jointed diagonal struts with axial stiffness calculated from the mechanical and geometric properties of the walls and from the elements that compose frame structures (beams and columns). The key parameter for obtaining this axial stiffness is equivalent strut width, which can be obtained using the analytical equations proposed by a number of authors in the specialized literature and presented in item 2.2 and summarized in Table 1.

In a linear elastic analysis, with data for thickness and longitudinal elastic modulus of the wall, the problem consists of determining the width of the cross section bar that simulates the presence of the wall. In other words, it is necessary to find the axial stiffness of the diagonal equivalent strut, which produces effects similar to that of the real structure.

The main advantage of the equivalent diagonal strut model is its simplicity, making it an attractive alternative for structural design purposes.

\subsection{Equations for calculating equivalent diagonal strut}

This item presents the formulation for obtaining equivalent diagonal strut (only one single-strut element), according to the specialized literature, for panels under lateral loads.
Figure 1 illustrates the dimensions involved in the equivalent diagonal strut model for masonry-infilled frames.

Most of the formulas found in the literature employ the parameter of relative stiffness of the frame to the infill $(\lambda)$, calculated by:

$$
\lambda=\sqrt[4]{\frac{E \cdot \operatorname{tsen}(2 \theta)}{4 \cdot E_{p} \cdot I_{p} \cdot h}}
$$

where

$\mathrm{E}=$ modulus of elasticity of the masonry panel;

$\mathrm{E}_{\mathrm{p}}=$ modulus of elasticity of the column;

$\mathrm{I}_{\mathrm{p}}=$ second moment of area of the column;

$\mathrm{t}=$ thickness of the infill panel;

$\mathrm{h}=$ height of infill panel (see Figure 1 );

$\theta=$ slope of the infill diagonal to the horizontal (see Figure 1).

As a matter of nomenclature, it is useful to express the product of relative stiffness $(\lambda)$ and height between beam axes $(H)$ as:

$$
\lambda_{\mathrm{H}}=\lambda \times \mathrm{H}
$$

Table 1 presents equations for the case of walls without openings. These equations are discussed in Asteris et al. [5].

There are usually considerable differences observed between the values obtained through the equations in Table 1 . The equation proposed by Mainstone [32] is the most well-known and is included in normative guidelines of FEMA 306 [27], FEMA 274 [28], FEMA 356 [29] and in Al-Chaar [33]. However, this equation, when compared to the others, supplies the lowest values for equivalent diagonal strut width, as emphasized in Asteris et al. [5] and Chrysostomou and Asteris [6].

For the case of walls with openings, there are two analytical equations for the purposes of a global analysis. Al-Chaar [33] proposes a reduction factor for the width obtained by Mainstone's equation

\section{Figure 1 - Single Diagonal-Strut Model for masonry-infilled frames}

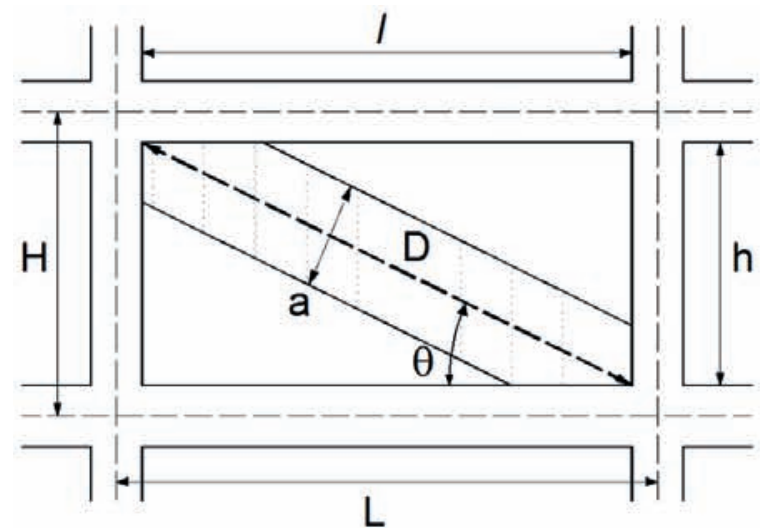

$\mathrm{a}=$ equivalent strut width

$\mathrm{t}=$ thickness of the infill panel

$\mathrm{D}=$ equivalent strut length

$\mathrm{h}=$ height of the infill panel

$l=$ height of the infill panel

$\theta=$ angle whose tangent is the infill height-

to-length aspect ratio

$\mathrm{H}=$ distance between centerlines of beams

$\mathrm{L}=$ distance between centerlines of columns 


\section{Figure 2 - Diagonal-Strut Models for masonry-infilled frames with openings}

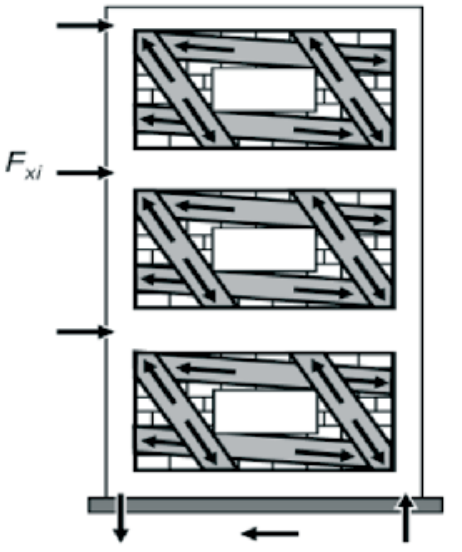

FEMA 356 (29)
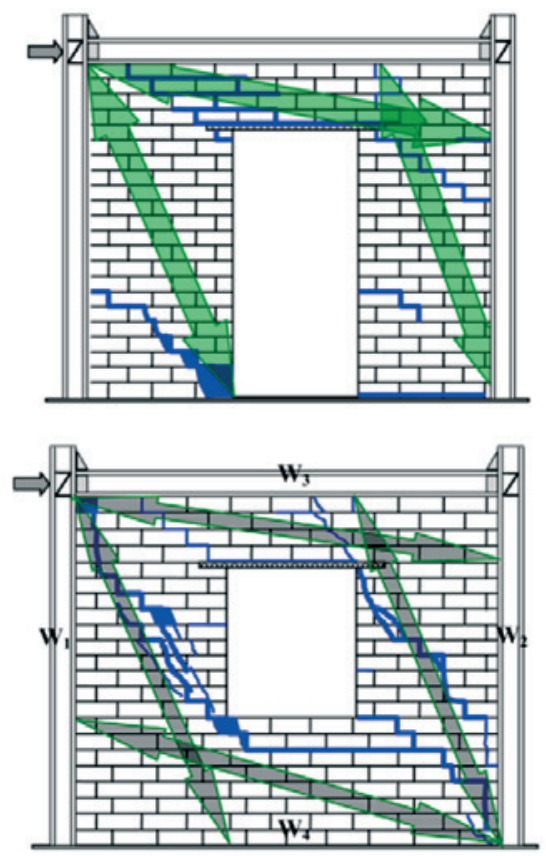

Tasnimi e Mohebkhah (25)
[32], as a function of the relation between the opening area and the area of the wall without openings, regardless of the position of the opening in the masonry panel:

$$
R=0,6 \cdot\left(\frac{A_{\text {op }}}{A_{\text {inf ill }}}\right)^{2}-1,6 \cdot\left(\frac{A_{\text {op }}}{A_{\text {inf ill }}}\right)+1
$$

where

$\mathrm{R}$ is the width reduction factor;

$A_{o p}$ is the area of opening;

$A_{\text {infill }}$ is the area of infill panel (without opening).

Mondal and Jain [13] proposed a simple equation to obtain a similar reduction factor, but applicable only to central openings:

$$
R=1-2,6 .\left(\frac{A_{\text {op }}}{A_{\text {inf ill }}}\right)
$$

However, as underlined in Asteris [14], the position of the openings exerts a good deal of influence on the lateral stiffness of the panelframe structure, underlining the need for calibration in models that employ plane or tridimensional finite elements.
Another model that can be used is the equivalent diagonal model defining compression struts to account for existent openings, as suggested in FEMA 356 [29] and Tasnimi and Mohebkhah [25] and illustrated in Figure 2. In this case, the equivalent widths of diagonal struts can be evaluated from the dimensions of the portions of the wall that are separated by the openings. However, to obtain equivalent diagonal strut width with greater precision, the ideal evaluation would employ the FEM.

\subsection{Equations for evaluation of the strength capacity of infill panels (stresses)}

This item presents equations for calculating the strength capacity of infill walls (stresses), which were used in the analyses via FEM in item 4. Strength capacity was extracted from FEMA 306 guidelines [27].

\subsubsection{Shear Strength of the infill $-f_{v}$}

According to Equation 8-4 of FEMA 306 [27], lateral load on the wall that produces sliding-shear failure $\left(\mathrm{F}_{\mathrm{Rv}}\right)$ can be evaluated by:

$$
F_{R v}=f_{v} . I t t=\left(\tau_{0}+\mu . \sigma\right) \text {.I.t }
$$


where

I and $t$ are respectively the length and the thickness of the infill panel;. $f_{v}$ is the shear strength (average) of the infill panel, which follows the Coulomb criterion:

$$
f_{v}=\tau_{0}+\mu . \sigma
$$

\section{being}

$\tau_{0}=$ cohesive capacity of the mortar beds;

$\mu=$ coefficient of sliding friction along the bed joint;

$\sigma=$ vertical compressive stress in the wall.

The vertical stress $\sigma$ results from the self-weight of the panel and the compression vertical component imposed on the wall by the panel-frame interaction (distortion cause by the lateral loads). The axial compressive force in diagonal strut is obtained by:

$$
\mathrm{D}_{\mathrm{Rv}}=\frac{\mathrm{F}_{\mathrm{Rv}}}{\cos \theta}
$$

The vertical component of the resultant diagonal compression is obtained by:

$D_{R v} \cdot \operatorname{sen} \theta=\frac{F_{R v} \cdot \operatorname{sen} \theta}{\cos \theta}=F_{R v} \cdot \operatorname{tg} \theta$

Thus, stress $\sigma$ at the average height of the wall can be calculated by: $\sigma=\frac{F_{\mathrm{Rv}} \cdot \operatorname{tg} \theta}{\mathrm{l} . \mathrm{t}}+0,5 \cdot \frac{\mathrm{W}_{\mathrm{alv}}}{\mathrm{l} . \mathrm{t}}$

where $\mathrm{W}_{\mathrm{alv}}$ is the self-weight of the panel. Knowing that $f_{v}=\frac{F_{R v}}{\text { rewritten as: }}$, compression vertical stress $\sigma$ can be
l.t

$$
\sigma=\mathrm{f}_{\mathrm{v}} \cdot \operatorname{tg} \theta+0,5 \cdot \sigma_{\mathrm{g}}
$$

being $\sigma_{g}$ the compression vertical stress due to the self-weight of the panel. From Equations 8 and 6:

$\mathrm{f}_{\mathrm{v}}=\tau_{0}+\mu .\left(\mathrm{f}_{\mathrm{v}} \cdot \operatorname{tg} \theta+0,5 \cdot \sigma_{\mathrm{g}}\right)$

Isolating $f_{v}$, leads to the equation of masonry shear strength:

$$
f_{v}=\frac{\tau_{0}+0,5 . \sigma_{g} \mu}{1-\mu \cdot \operatorname{tg} \theta}
$$

In the absence of experimental results, cohesion can be obtained by:

$$
\tau_{0}=\frac{f_{c, 0}}{20}
$$

where $f_{c, 0}$ is the strength of masonry in the horizontal direction, which, according to FEMA 306 [27], can be considered $50 \%$ of the stacked prism strength $\left(\mathrm{f}_{\mathrm{p}}\right)$.

Thus, cohesion can be obtained simply by:

$$
\tau_{0}=\frac{f_{p}}{40}
$$

\subsubsection{Diagonal Tension Strength of the infill $-f_{t, \theta}$}

FEMA 306 [27] recognizes, in item 8.3.1, that masonry tensile strength depends on the angle of tensile principal stresses in relation to the bed joints. In the absence of experimental results, masonry tensile strength can be obtained according to Equation 8-12 of FEMA 306 [27]:

$$
f_{t, 0}=\frac{f_{c, 0}}{20}
$$

Thus, diagonal tension strength can be obtained simply by:

$$
f_{t, \theta}=\frac{f_{p}}{40}
$$

\subsubsection{Diagonal Compression Strength of the infill $-f_{c, \theta}$}

Based on Equation 8-10 of FEMA 306 [27], diagonal compression strength assumed for the panel is:

$$
f_{c, \theta}=f_{c, 0}
$$

Thus:

$$
f_{c, \theta}=\frac{f_{p}}{2}
$$

\subsection{Equations for evaluating the strength capacity of infill panels (diagonal forces)}

This item presents equations for calculating axial force strengths associated to the three failure modes, for analyses with the equivalent diagonal strut model (DSM). These equations were used in the simulations in item 4.1 and are in accordance with FEMA 306 [27]. 


\subsubsection{Shear strength of the infill $-D_{R v}$}

The axial force strength in the equivalent diagonal strut associated to sliding-shear failure is the same as that presented in Equation 7: $\mathrm{D}_{\mathrm{Rv}}=\frac{\mathrm{F}_{\mathrm{Rv}}}{\cos \theta}$

where $F_{R v}$ is the lateral load on the wall that produces sliding-shear failure, which can be obtained with the formulation presented in Equations 5 to 11.

\subsubsection{Diagonal tension ttrength of the infill $-D_{R t}$}

According to Equation 8-11 of FEMA 306 [27], lateral loads on the wall that produce diagonal tensile failure $\left(\mathrm{F}_{\mathrm{Rt}}\right)$ can be evaluated by:

$$
F_{R t}=\frac{2 \sqrt{2} \cdot f_{t, \theta} \cdot I t}{\frac{l}{h}+\frac{h}{l}}
$$

\section{where}

$f_{t, \theta}$ is the diagonal tension strength of the panel, calculated according to item 2.3.2.

$\mathrm{I}, \mathrm{h}$ and $\mathrm{t}$ are geometric parameters of the wall, as shown in Figure 1. Thus, the axial force strength in the equivalent diagonal strut associated to diagonal tensile failure of the wall is obtained by:

$$
\mathrm{D}_{\mathrm{Rt}}=\frac{\mathrm{F}_{\mathrm{Rt}}}{\cos \theta}
$$

\subsubsection{Diagonal compression strength of the infill $-f_{c, \theta}$}

According to Equation 8-10 of FEMA 306 [27], lateral loads on the wall that produce diagonal compression failure $\left(\mathrm{F}_{\mathrm{RC}}\right)$ can be evaluated by:

$$
\mathrm{F}_{\mathrm{Rc}}=\text { a.t. } \mathrm{f}_{\mathrm{c}, \theta} \cdot \cos \theta
$$

where

a is equivalent strut width;

$\mathrm{t}$ is wall thickness;

$f_{c, \theta}$ is diagonal compression strength.

FEMA 306 [27] considers that diagonal compression strength is equal to strength of masonry in the horizontal. Thus, axial force strength in the equivalent diagonal strut associated to diagonal compression failure is obtained by:

$$
D_{\mathrm{Rc}}=\frac{F_{\mathrm{Rc}}}{\cos \theta}
$$

\section{Methodology and modeling}

Numerical simulations were performed in this study to analyze single-story one-bay infilled frames. Each reinforced concrete frame was composed of two columns and two beams.

In order to include the masonry panels as resistant elements, diagonal strut (DSM) models using plane stress state finite elements (see Figure 3) were employed. For the diagonal strut structural

Figure 3 - Models used for modelling of the frame and infill-panel elements

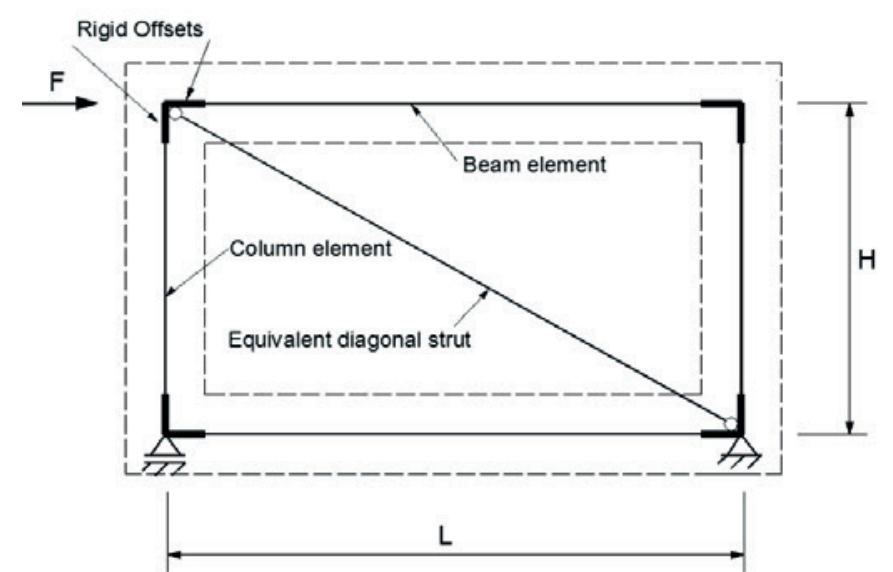

Diagonal-Strut Model - DSM

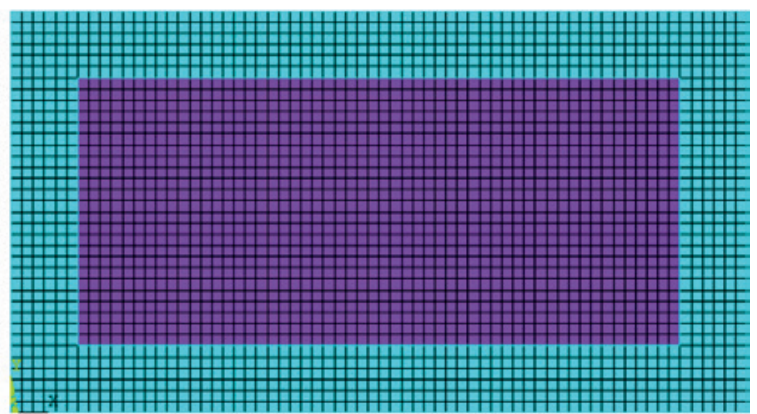

FEM Model: State of plane stresses 
analysis, a software program for solving plane frames was utilized. The equivalent strut width was calculated according to Mainstone's equation [32] (see Table 1). To account for beam-column nodes dimensions, rigid-end-offsets in beams and pillars were defined according to NBR 6118.

Analysis of infilled frames via FEM was performed using the ANSYS program. The element PLANE182 was used for modeling both the concrete structure and the infilled frame. This finite element possesses four nodes, each with two degrees of freedom: translation in nodal $X$ and $Y$ directions (the $X Y$ plane, in this case, being the plane of the infilled frame). In terms of discretization, $10 \mathrm{~cm} \times 10 \mathrm{~cm}$ finite elements were defined and, as needed, $5 \mathrm{~cm} \times 5 \mathrm{~cm}$ elements.

The elements CONTAT171/TARGE169 were used to account for the possibility of contact, separation and sliding between concrete frame structures and infill walls, in the surface-to-surface contact simulation. Normal contact stiffness factor (FKN) values were found for each model, not only in regard to numeric convergence but also to the stabilization of values for contact pressure and penetration among surfaces. In all the models, the maximum penetration between concrete frame structures and masonry was lower than $0.1 \mathrm{~mm}$. Friction between the concrete structure and the wall was considered using the
Coulomb model, limiting the maximum contact friction to $\alpha . f_{v}$. A value of $\alpha=1.5$ was adopted to convert average (conventional) shear stress on the wall to shear stress in the finite element.

Initially, lateral loads were applied to produce interstory drifts equal to H/850 in the models with no walls. These forces were reapplied in the models with walls to analyze stresses in the masonry panels, in order to verify their stress level when two consecutive stories are subjected to the drift limit recommended by NBR 6118 [30].

In all the analyses, the materials were considered isotropic and of an elastic-linear behavior. A material linear analysis was employed because of the stress level applied to infilled frames (corresponding to service conditions of the structure). The materials were considered isotropic because of simulations carried out by Doudoumis [12], which showed the insignificant effects of the orthotropy of the wall on the behavior of the infilled frames with $\mathrm{L} / \mathrm{H}>1.5$.

\section{Numeric simulations}

\subsection{Example 1: Infilled frames without openings}

In this example, four masonry-infilled frames were analyzed. The

Figure 4 - Compressive principal elastic strains- FEM Models
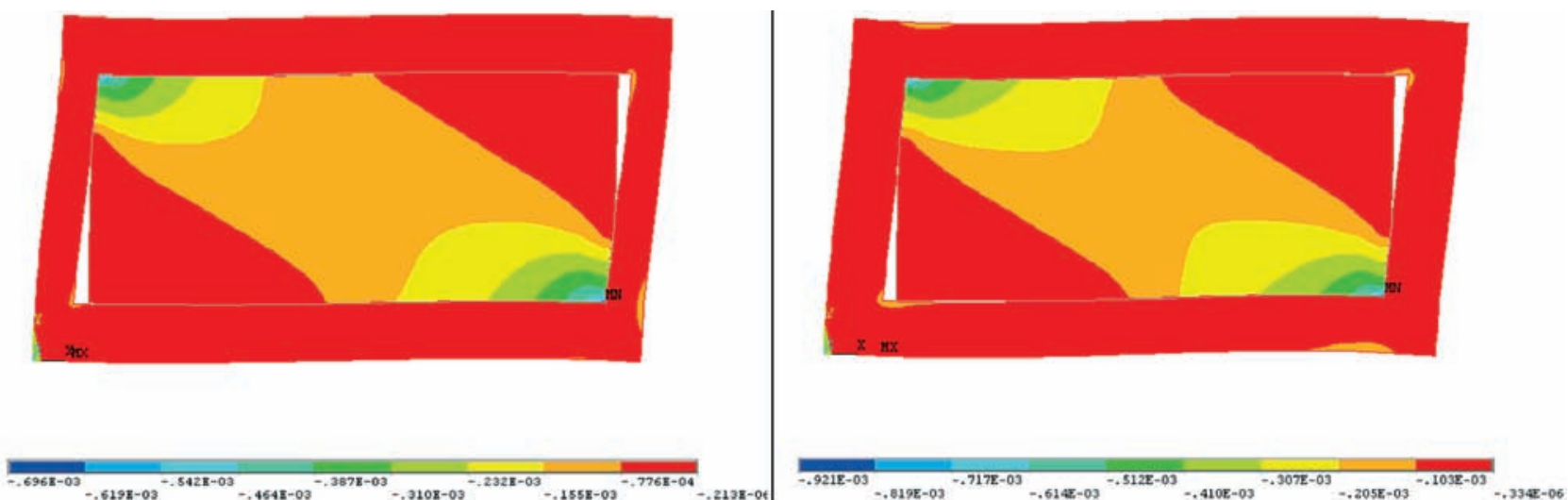

Column 20x40

Column 20x60
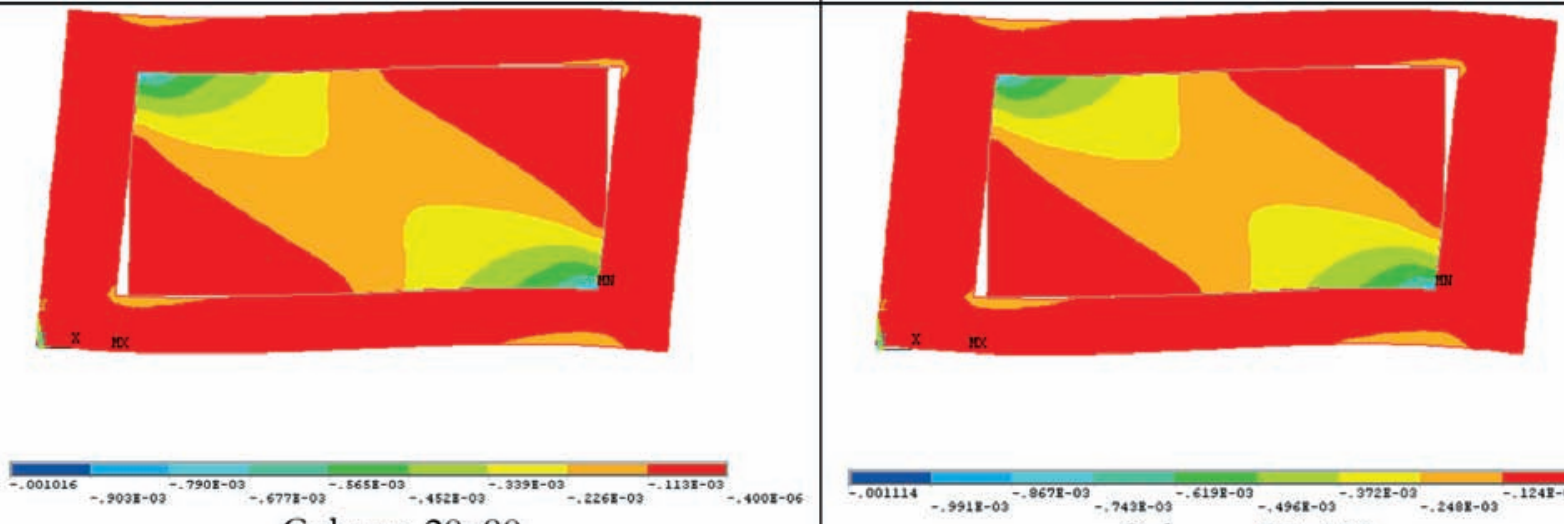

Column 20x80

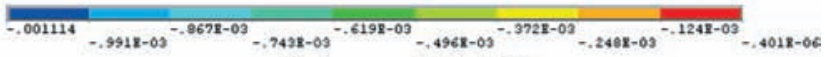

Column 20x100 
theoretical span of the beams $(L)$ was set at $6.0 \mathrm{~m}$ and the distance between the beam axes $(\mathrm{H})$ was set at $3.0 \mathrm{~m}$. The columns presented rectangular cross sections with the following dimensions $(\mathrm{cm})$ $20 \times 40,20 \times 60,20 \times 80$ and $20 \times 100$. The rectangular cross section of the beams was set at 20x60. A $28.000 \mathrm{MPa}$ longitudinal elastic modulus was assumed for the concrete structure, corresponding to a concrete with compressive strength of $\mathrm{C} 25$. The infill walls were $20 \mathrm{~cm}$ in thickness and a value of $1.50 \mathrm{MPa}$ was assumed for stacked prism strength $\left(f_{p}\right)$. The longitudinal elastic modulus of the wall $(E)$ was obtained from the NBR 15812 equation [39] $(E=600$.

\section{Figure 5 - Acting stresses related to diagonal tension and shear in infill walls - FEM models (values in $\mathrm{kN} / \mathrm{m}^{2}$ )}

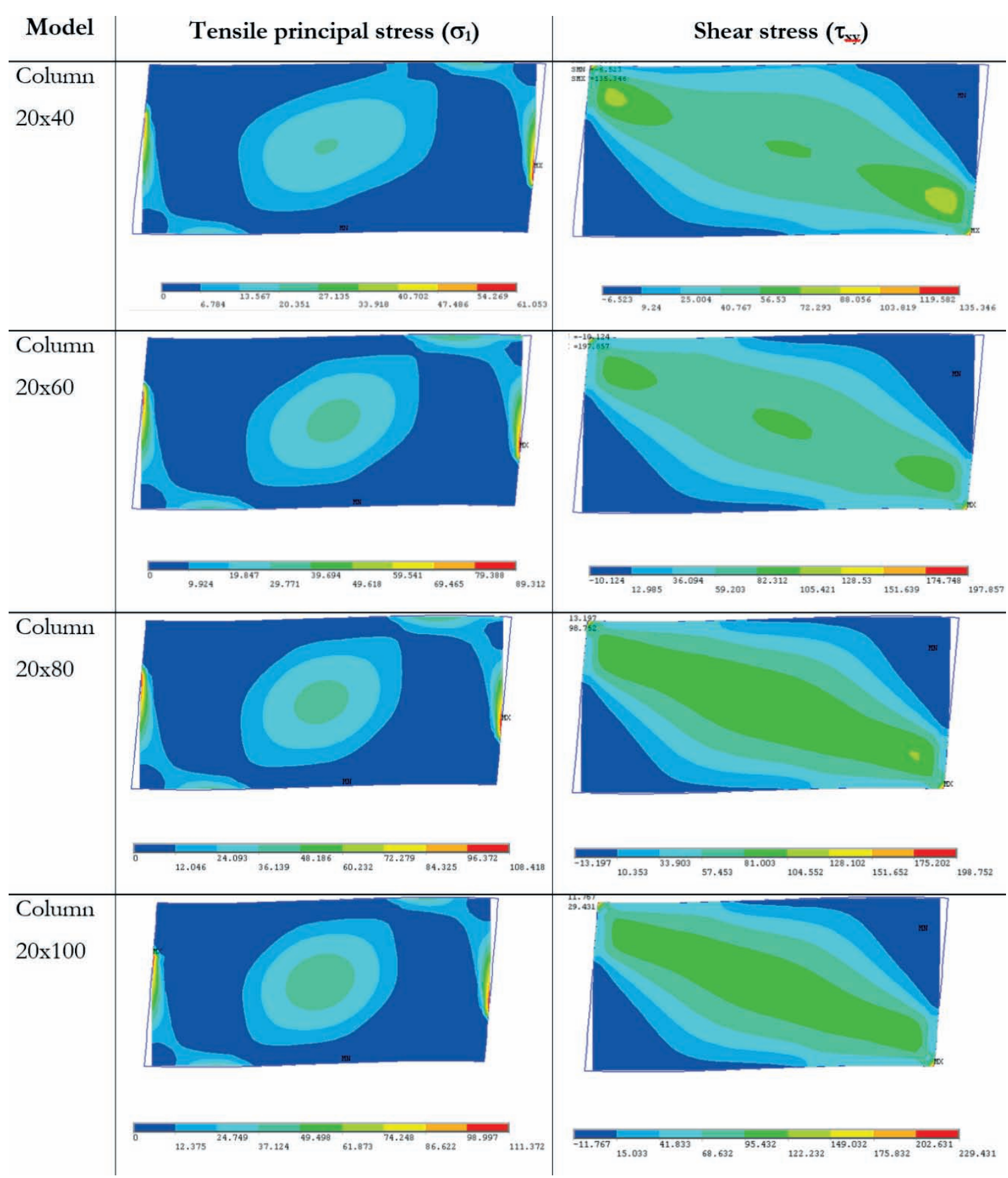


$\left.f_{p}\right)$. A value of $\mu=0.7$ was considered for the coefficient of friction between the concrete structure and the infill frame.

\section{Results and conclusions of the simulations}

Figure 4 presents diagrams of the compressive principal elastic strains for the four infilled frames and shows the deformed shapes of the frames. It is possible to confirm the occurrence of separation between the concrete structure and the infill wall in certain places and the formation of struts in regions of contact.

Figures 5 and 6 show, respectively, the results for stresses related to diagonal tension, shear and diagonal compression. In the FEM results, $\sigma_{1}$ is the tensile principal stress, $T_{x y}$ is the shear stress at the plane of the wall and $\sigma_{3}$ is the compressive principal stress.

Table 2 shows a summary of the results presented in Figures 5 and 6 (FEM) and the results obtained with the diagonal strut model. It is important to note that in Table 2, the values for $\sigma_{3}$ were extracted at a distance of $10 \mathrm{~cm}$ from the internal contour of the concrete frame structures, in order to prevent the extraction of values owing to the concentration of stresses. Extraction of the tensile principal stresses $\sigma_{1}$ and shear stresses $\mathrm{T}_{\mathrm{xy}}$ proceeded in a similar way.
The main findings for this example are:

- The greater the stiffness of the column, the greater the stress imposed in the infill walls, even when the interstory drift ratio is the same. This is an important aspect for the designer to consider, since even when complying with interstory drift limits recommended in design norms for conventional modeling, it is possible for walls fixed to framed structures with robust columns to suffer damage under elevated stresses.

- In the models with $20 \mathrm{~cm} \times 80 \mathrm{~cm}$ and $20 \mathrm{~cm} \times 100 \mathrm{~cm}$ columns, cracking would have occurred had the frame structures been subjected to the interstory drift ratio limits from NBR 6118 $(1 / 850 \mathrm{rad})$ for conventional modeling. Greater caution is therefore recommended in employing the interstory drift limit of $H / 850$ to columns with significantly greater stiffness than that of the beams. In this case, modeling of the walls, even in single-story one-bay infilled frames, can provide approximate information as to their stress level.

- The expected failure modes occurred by diagonal tension and shearing, while diagonal compression failure did not occur. Acting axial forces for the diagonal strut model were between $31 \%$ and $40 \%$ of the compressive axial force strength (diagonal

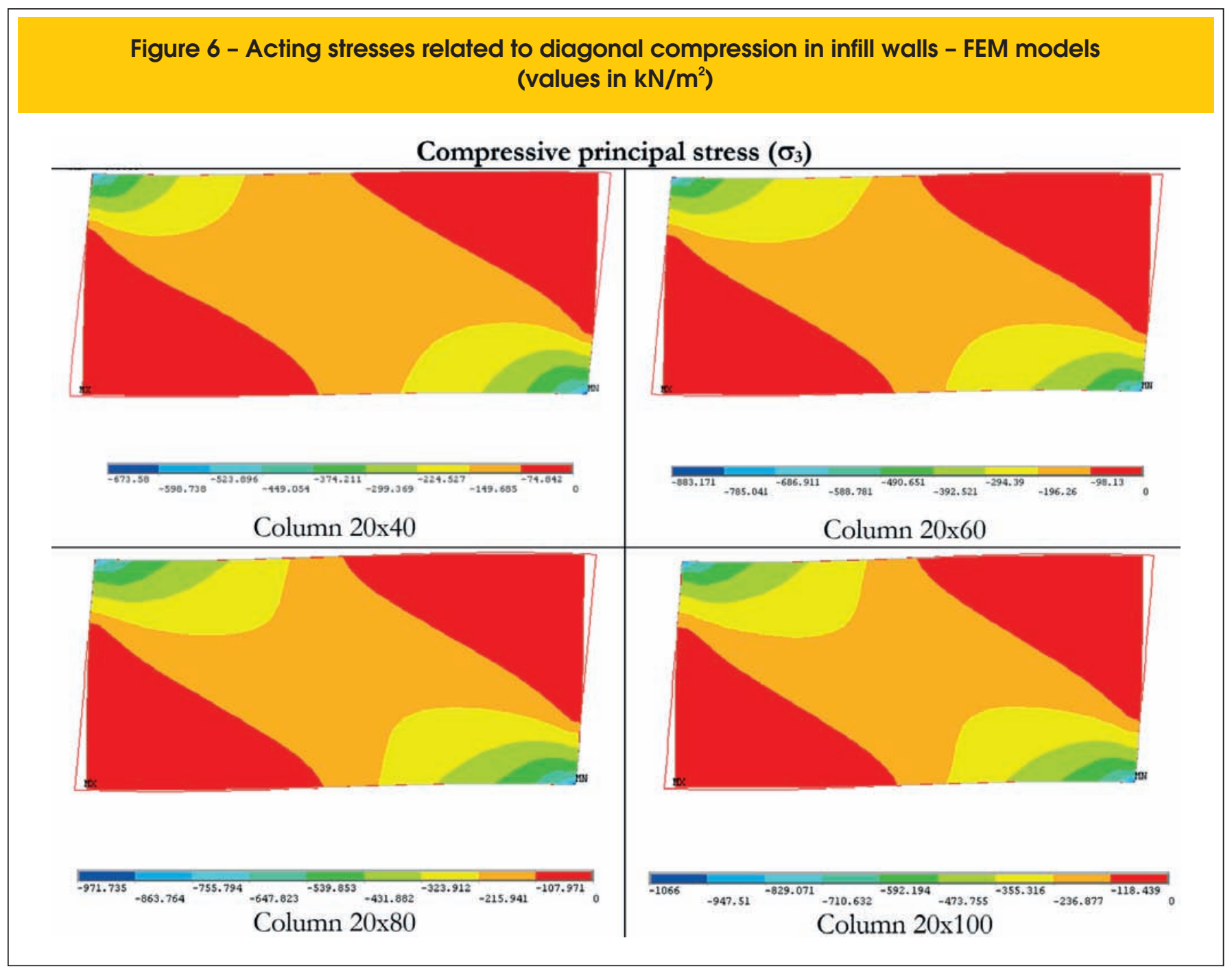




\section{Table 2 - Summary of the results of the Example 1 - Maximum Internal Forces (Stresses) vs. Strength (Forces in $\mathrm{kN}$ and stresses in $\mathrm{kN} / \mathrm{m}^{2}$ )}

\begin{tabular}{|c|c|c|c|c|c|}
\hline \multicolumn{2}{|c|}{ Model } & $\begin{array}{l}\text { Diagonal } \\
\text { tension }\end{array}$ & Shear & $\begin{array}{l}\text { Diagonal } \\
\text { compression }\end{array}$ & $\begin{array}{c}\text { Probable type } \\
\text { of failure }\end{array}$ \\
\hline \multirow{2}{*}{$\begin{array}{l}\text { Column } \\
20 \times 40\end{array}$} & DSM & $\begin{array}{l}D_{S d}=34,44 \\
D_{R t}=46,80\end{array}$ & $\begin{array}{l}D_{S d}=34,44 \\
D_{R V}=83,56\end{array}$ & $\begin{array}{c}D_{S d}=34,44 \\
D_{R C}=111,51\end{array}$ & Does not occurs \\
\hline & FEM & $\begin{array}{l}\sigma_{1}=21,00 \\
f_{t, \theta}=37,50\end{array}$ & $\begin{aligned} \tau_{x y} & =75,00 \\
\alpha . f_{v} & =102,86\end{aligned}$ & $\begin{array}{l}\sigma_{3}=374,00 \\
f_{c, \theta}=750,00\end{array}$ & Does not occurs \\
\hline \multirow{2}{*}{$\begin{array}{l}\text { Column } \\
20 \times 60\end{array}$} & DSM & $\begin{array}{l}D_{S d}=44,56 \\
D_{R t}=46,52\end{array}$ & $\begin{array}{l}D_{S d}=44,56 \\
D_{R v}=82,35\end{array}$ & $\begin{array}{c}D_{S d}=44,56 \\
D_{R c}=121,85\end{array}$ & Does not occurs \\
\hline & FEM & $\begin{array}{l}\sigma_{1}=32,00 \\
f_{t, \theta}=37,50\end{array}$ & $\begin{array}{c}\tau_{x y}=93,00 \\
\alpha . f_{v}=104,52\end{array}$ & $\begin{array}{l}\sigma_{3}=490,00 \\
f_{c, \theta}=750,00\end{array}$ & Does not occurs \\
\hline \multirow{2}{*}{$\begin{array}{l}\text { Column } \\
20 \times 80\end{array}$} & DSM & $\begin{array}{l}D_{S d}=49,97 \\
D_{R t}=46,23\end{array}$ & $\begin{array}{l}D_{S d}=49,97 \\
D_{R v}=81,22\end{array}$ & $\begin{array}{c}D_{S d}=49,97 \\
D_{R c}=128,41\end{array}$ & Diagonal tension \\
\hline & FEM & $\begin{array}{l}\sigma_{1}=40,00 \\
f_{t, \theta}=37,50\end{array}$ & $\begin{array}{r}\tau_{x y}=128,10 \\
\alpha . f_{v}=106,37\end{array}$ & $\begin{array}{l}\sigma_{3}=540,00 \\
f_{c, \theta}=750,00\end{array}$ & $\begin{array}{c}\text { Diagonal tension/ } \\
\text { Shear }\end{array}$ \\
\hline \multirow{2}{*}{$\begin{array}{l}\text { Column } \\
20 \times 100\end{array}$} & DSM & $\begin{array}{l}D_{S d}=53,07 \\
D_{R t}=45,90\end{array}$ & $\begin{array}{l}D_{S d}=53,07 \\
D_{R v}=80,19\end{array}$ & $\begin{array}{c}D_{S d}=53,07 \\
D_{R c}=132,63\end{array}$ & Diagonal tension \\
\hline & FEM & $\begin{array}{l}\sigma_{1}=44,00 \\
f_{t, \theta}=37,50\end{array}$ & $\begin{array}{r}\tau_{x y}=120,00 \\
\alpha . f_{v}=108,44\end{array}$ & $\begin{array}{l}\sigma_{3}=592,00 \\
f_{c, \theta}=750,00\end{array}$ & $\begin{array}{c}\text { Diagonal tension/ } \\
\text { Shear }\end{array}$ \\
\hline
\end{tabular}

compression). In the FEM, the maximum compressive principal stresses were between $50 \%$ and $79 \%$ of the diagonal compression strength of the infill.

\section{Observations on determining diagonal strut width}

As mentioned in item 2.2 , there are usually considerable differences among the values provided by the diagonal strut width equations from Table 1. For this example, width values obtained from the different equations were calculated and summarized in Table 3. For structural design purposes, it is more important to evaluate the differences in terms of interstory drifts and internal forces (especially the latter, in order to predict the failure modes in the panels).
Table 4 shows the average compression stress in equivalent diagonals struts (obtained from the ratio between compressive axial force and diagonal strut cross section area). Table 4 also shows compressive principal stresses near the center of the wall obtained by FEM (see Figure 6), for comparison with the compression principal stresses obtained by DSM. Table 5 shows values for relative lateral deflections between beam axes for both models (DSM and FEM).

Despite the considerable differences in diagonal strut width values shown in Table 3, such differences were not found in regard to stresses, which can be noted from the results shown in Table 4. For this example, Mainstone's equation [32] gave the greatest diagonal strut compression stress values, thus proving to be the most conservative. The Liauw and Kwan equation [35] gave stress

Table 3 - Equivalent strut width - values in $\mathrm{cm}$

\begin{tabular}{|c|c|c|c|c|}
\hline Equation & Column $20 \times 40$ & Column $20 \times 60$ & Column $20 \times 80$ & Column $20 \times 100$ \\
\hline Mainstone (32) & 74,34 & 81,23 & 85,61 & 88,42 \\
\hline Hendry (34) & 186,61 & 203,72 & 222,21 & 241,27 \\
\hline Liauw e Kwan (35) & 133,52 & 154,07 & 169,99 & 182,95 \\
\hline Decanini e Fantin (36) & 180,95 & 234,37 & 278,76 & 316,17 \\
\hline Paulay e Priestley (37) & 152,32 & 147,73 & 143,18 & 138,65 \\
\hline Durrani e Luo (38) & 97,55 & 102,67 & 108,93 & 115,34 \\
\hline Chrysostomou e Asteris (6) & 114,70 & 125,33 & 132,08 & 136,42 \\
\hline
\end{tabular}




\section{Table 4 - Compressive average stresses (DSM) and compressive principal stresses near to the center of the infill walls (FEM) - values in $\mathrm{kN} / \mathrm{m}^{2}$}

\begin{tabular}{|c|c|c|c|c|}
\hline Model & Column $20 \times 40$ & Column $20 \times 60$ & Column 20x80 & Column $20 \times 100$ \\
\hline DSM: Mainstone (32) & 231,63 & 274,28 & 291,85 & 300,09 \\
\hline DSM: Hendry (34) & 139,54 & 181,23 & 197,68 & 204,23 \\
\hline DSM: Liauw e Kwan (35) & 171,84 & 210,10 & 225,48 & 232,58 \\
\hline DSM: Decanini e Fantin (36) & 142,38 & 167,04 & 174,38 & 176,58 \\
\hline DSM: Paulay e Priestley (37) & 158,85 & 214,47 & 243,05 & 259,96 \\
\hline DSM: Durrani e Luo (38) & 203,84 & 251,63 & 269,91 & 277,18 \\
\hline $\begin{array}{c}\text { DSM: Chrysostomou } \\
\text { e Asteris (6) }\end{array}$ & 187,23 & 231,48 & 251,13 & 261,54 \\
\hline FEM: ANSYS & 149,69 & 196,26 & 215,94 & 236,88 \\
\hline
\end{tabular}

Table 5 - Interstorey drifts - values in $\mathrm{mm}$

\begin{tabular}{|c|c|c|c|c|}
\hline Model & Column $20 \times 40$ & Column $20 \times 60$ & Column $20 \times 80$ & Column $20 \times 100$ \\
\hline DSM: Mainstone (32) & 1,910 & 2,233 & 2,356 & 2,407 \\
\hline DSM: Hendry (34) & 1,159 & 1,484 & 1,603 & 1,645 \\
\hline DSM: Liauw e Kwan (35) & 1,422 & 1,716 & 1,826 & 1,870 \\
\hline DSM: Decanini e Fantin (36) & 1,182 & 1,370 & 1,417 & 1,425 \\
\hline DSM: Paulay e Priestley (37) & 1,316 & 1,752 & 1,966 & 2,088 \\
\hline DSM: Durrani e Luo (38) & 1,684 & 2,051 & 2,181 & 2,225 \\
\hline $\begin{array}{c}\text { DSM: Chrysostomou } \\
\text { e Asteris (6) }\end{array}$ & 1,548 & 1,888 & 2,031 & 2,101 \\
\hline FEM: ANSYS & 1,562 & 1,990 & 2,227 & 2,276 \\
\hline
\end{tabular}

results closer to those given by the FEM. In terms of interstory drift, there were not substantial differences, and the Durrani and Luo [38] equation gave results closer to those of the FEM.

\subsection{Example 2: Infilled frames with openings}

For the second example, masonry-infilled frames similar to those in item 4.1 were analyzed. These frames were investigated by Silva [40], however only for models with central openings. The main objective of this example is to demonstrate the influence of the openings on the panel-frame structure.

The theoretical span of the beams $(\mathrm{L})$ was set at $6.0 \mathrm{~m}$ and the distance between beam axes $(\mathrm{H})$ was set at $2.80 \mathrm{~m}$. Columns and beams were $20 \times 40$ and $20 \times 50$ rectangular sections, respectively. A $25.000 \mathrm{MPa}$ longitudinal elastic modulus was assumed for the concrete structure. The infill walls were $19 \mathrm{~cm}$ in thickness and a value of $1.50 \mathrm{MPa}$ was assumed for stacked prism strength (fp). The remaining masonry parameters were the same as though presented in the example in item 4.1.

Figure $7 a$ ) illustrates the geometry of model L1 (wall without openings). The remaining models - $\mathrm{L} 1 \mathrm{~J} 1 \mathrm{C}, \mathrm{L} 1 \mathrm{~J} 2 \mathrm{C}$ and $\mathrm{L} 1 \mathrm{~J} 3 \mathrm{C}-$ pres- ent the same dimensions as model L1, however with openings as shown in Figure $7 \mathrm{~b}$.

Table 6 shows the values for relative lateral deflections between beam axes. Although it is expected that lateral deflections increase with an increasing area of opening in the wall, quantifying the effects of the openings on the lateral stiffness of the structure can be important in analyses of excessive vibrations of structures using DSM. In this case, calibrations of diagonal strut axial stiffness can be carried out in regard to interstory drift given in FEM analyses, since the equations shown in Table 1 apply only to walls without openings. Examples of this type of calibration are presented in Silva et al. [41].

Figure 8 shows diagrams for compressive principal elastic strains and the deformed shapes of the frames. Figures 9 to 11 demonstrate, respectively, the results for stresses related to diagonal tension, shear and diagonal compression.

Table 7 shows a summary of results presented in Figures 9 to 11 . As in item 4.1, the values in Table 7 were obtained from a distance of $10 \mathrm{~cm}$ from the internal contour of the concrete frame structures, in order to prevent extracting values resultant from the concentration of stresses. 


\section{Figure 7 - Models analyzed in Example 2 (units of measurement in $\mathrm{cm}$ )}

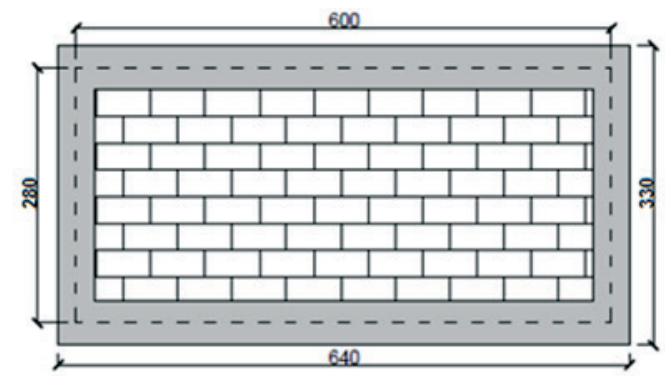

A Model LI (without openings)

L1J1C
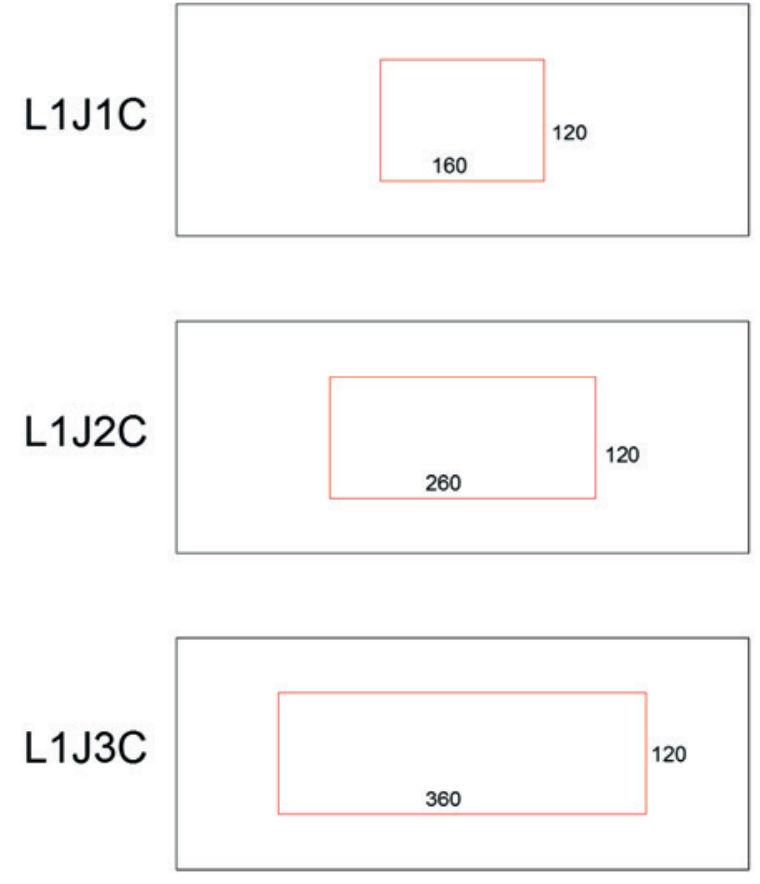

B Models LI with openings
The results in Figures 9 to 11 and Table 7 suggest that the presence of openings, in addition to forming two main diagonal struts, leads to a reduction of values for compressive principal stresses when compared to models without openings (L1). In contrast, the introduction of openings led to a notable increase in tensile principal stresses and shear stresses, when compared to model L1. Therefore, shear failure and diagonal tensile failure can be expected in walls with openings, in the case of the interstory drift limit presented in NBR 6118 (1/850 rad).

\section{Conclusions and final considerations}

The main aim of this study was to demonstrate how to verify the service limit state associated to excessive lateral deflections when infill panels are included in the structural model, in order to evaluate possible states of cracking in seals.

Even if the main structure is designed without considering the contribution of masonry as resistant elements, it may be important to utilize modeling that includes infill walls when verifying the service limit states. This modeling has the advantage of allowing for an identification of building panels that may potentially present problems as a result of the masonry-structure interaction.

In conventional modeling (structural model without walls), this verification is carried out in a more practical manner, controlling for lateral deflections of the structure, which should not exceed the drift limits recommended by codes (NBR 6118 and NBR 15575). Infill walls can be included in the structural model by using equivalent diagonal struts or by using plane or tridimensional finite elements (FEM). In both cases, in order to verify excessive vibrations of excessive lateral deflections, it is necessary to know a number of geometric and mechanical parameters of the infill walls, including: thickness $(\mathrm{t})$; height $(\mathrm{h})$; length $(\mathrm{l})$; position and dimensions of openings (when present); longitudinal elastic modulus $(E)$; shear strength $\left(D_{R_{v}}\right.$ ou $\left.f_{v}\right)$; diagonal tension strength $\left(D_{R_{t}}\right.$ ou $\left.f_{t \theta}\right)$ and diagonal compression strength $\left(D_{R c}\right.$ ou $\left.f_{c, \theta}\right)$. In this type of modeling, greater attention should be given to the comparison between acting internal forces (or stresses) and strength capacity (axial forces or stresses), in regard to the three possible failure modes (diagonal tension, shear and diagonal compression).

Clearly, conventional modeling is advantageous due to its simplicity and because it does not require the knowledge of geometric and mechanical parameters of the masonry. However, as the results from Example 1 of this study indicate, it is possible that walls fixed to frames with pillars presenting great stiffness are

Table 6 - Influence of the area of opening on lateral stiffness of the models

\begin{tabular}{|cccc|}
\hline Model & Area of opening $\left(\mathrm{m}^{2}\right)$ & $\begin{array}{c}\text { Area of opening/ } \\
\text { Area of infill }\end{array}$ & Interstorey drift $(\mathrm{mm})$ \\
\hline LI & 0 & 0 & 1,377 \\
\hline LIJIC & 1,92 & 0,149 & 1,691 \\
\hline LIJ2C & 3,12 & 0,242 & 1,993 \\
LIJ3C & 4,32 & 0,335 & 2,360 \\
\hline L1 without wall & 12,88 & 1 & 3,294 \\
\hline
\end{tabular}


Figure 8 - Deformed shape and compressive principal strains - FEM models

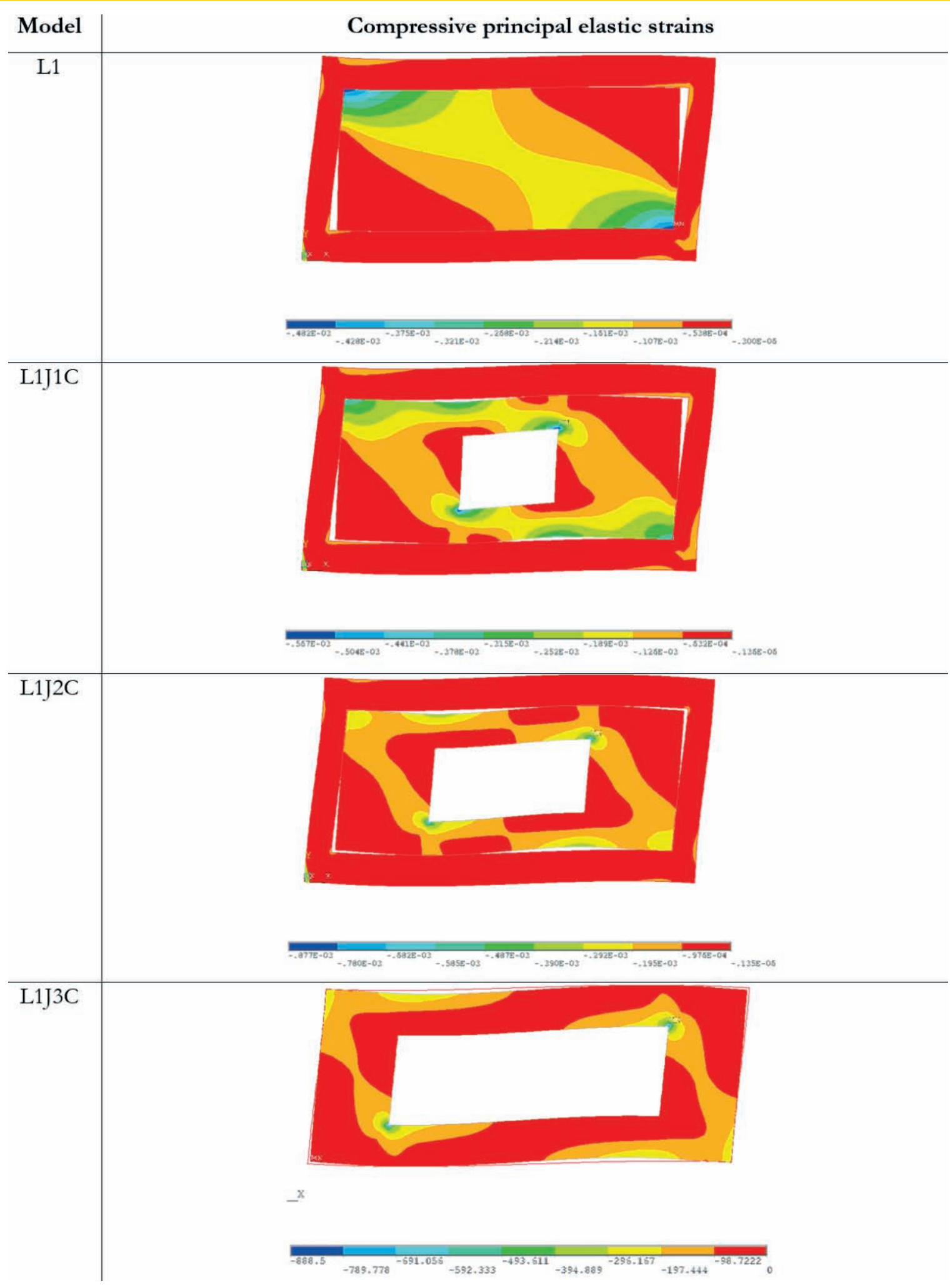


Figure 9 - Acting stresses related to diagonal tension in infill walls - FEM models (values in $\mathrm{kN} / \mathrm{m}^{2}$ )

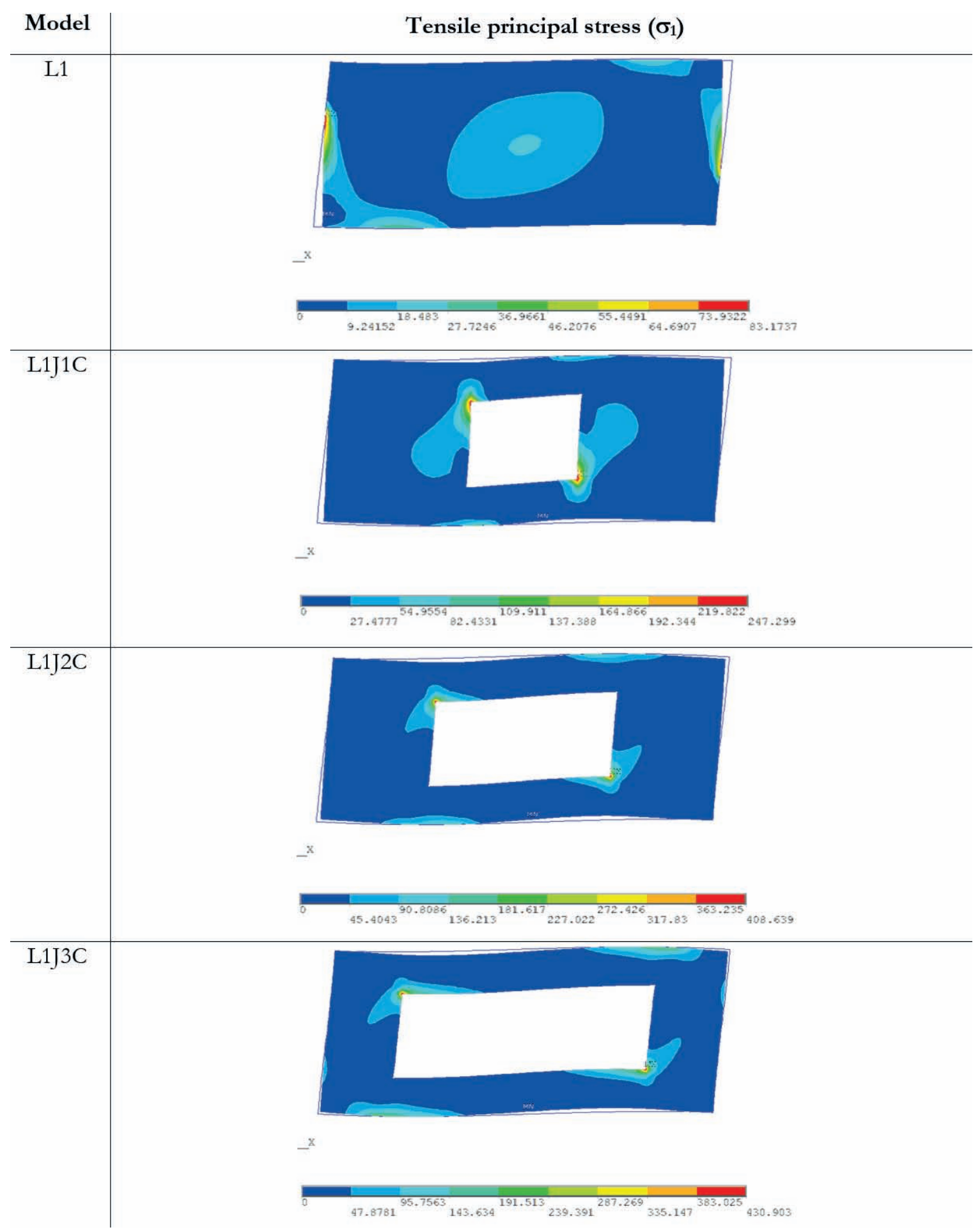


Figure 10 - Acting stresses related to shear in infill walls - FEM models (values in $\mathrm{kN} / \mathrm{m}^{2}$ )

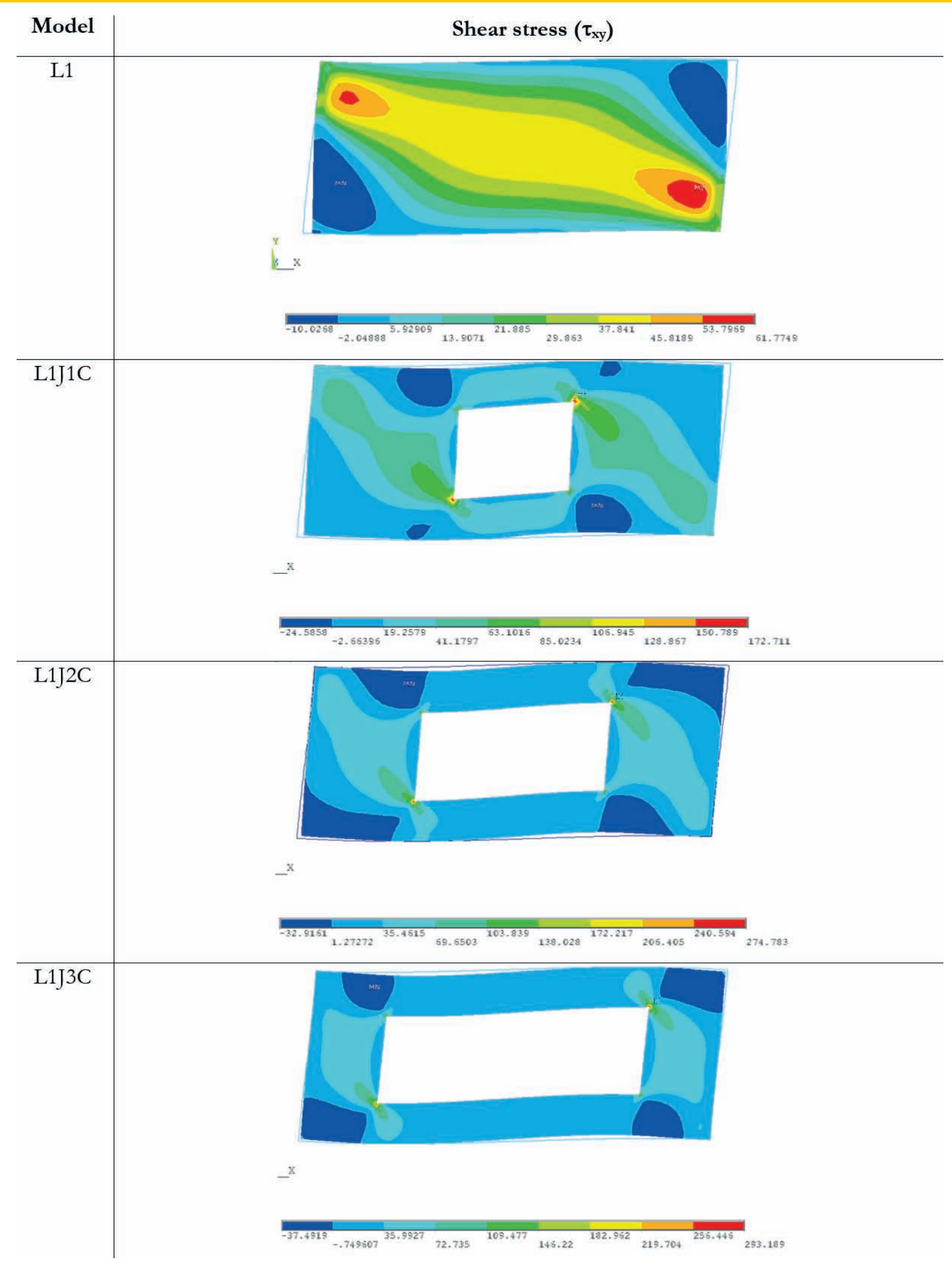


Figure 11 - Acting stresses related to diagonal compression in infill walls - FEM models (values in $\mathrm{kN} / \mathrm{m}^{2}$ )

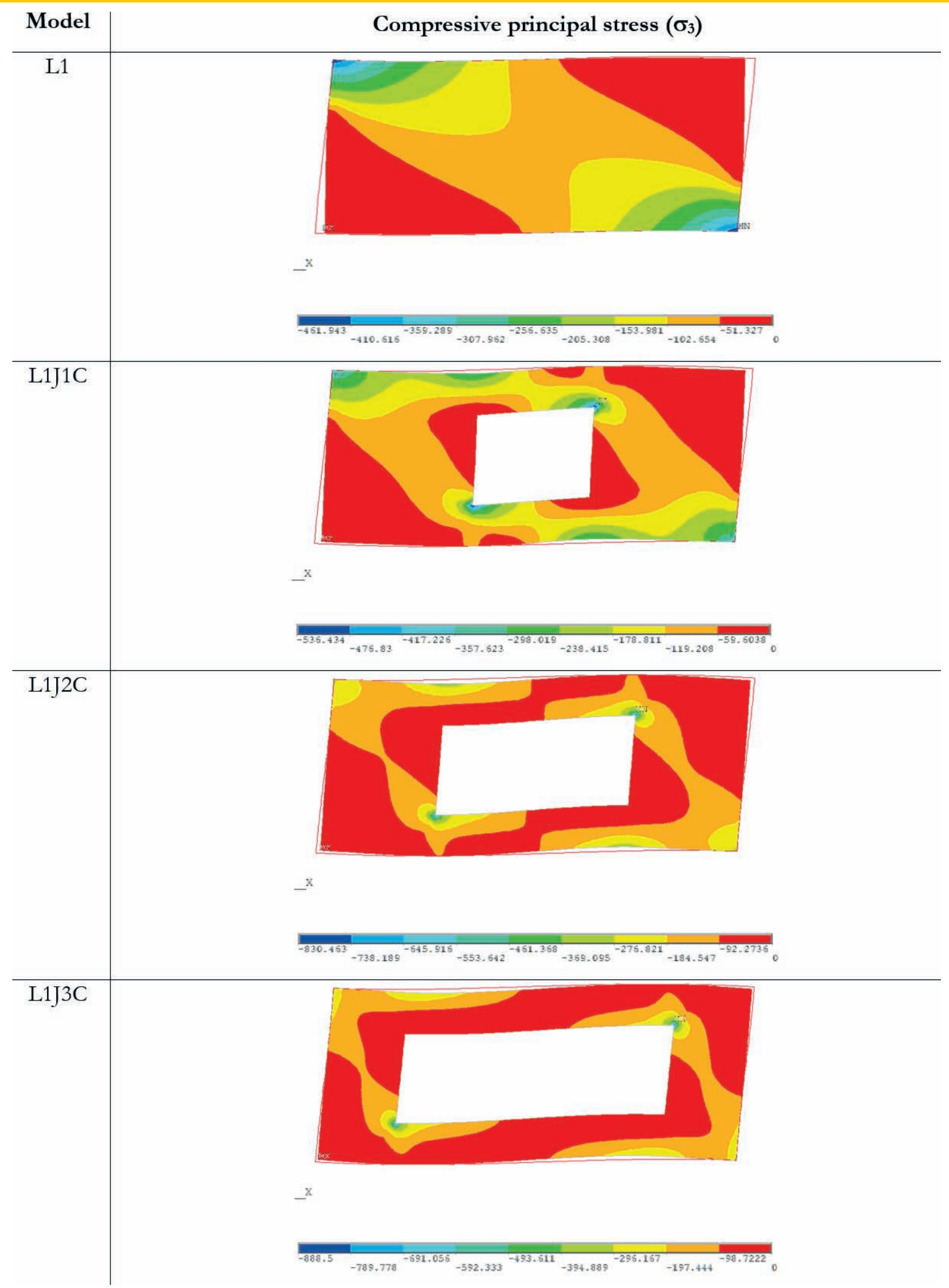


Table 7 - Summary of the results of the Example 2 - Maximum Acting Stresses vs. Strength $\left(\mathrm{kN} / \mathrm{m}^{2}\right)$

\begin{tabular}{|c|c|c|c|c|c|c|c|}
\hline \multirow{2}{*}{ Model } & \multicolumn{3}{|c|}{ Maximum acting stresses } & \multicolumn{3}{|c|}{ Strength capacity } & \multirow{2}{*}{ Probable type of failure } \\
\hline & $\sigma_{1}$ & $\tau_{x y}$ & $\sigma_{3}$ & $f_{t, \theta}$ & $\sigma_{f v}$ & $\mathbf{f}_{\mathrm{c}, \theta}$ & \\
\hline L1 & 18,48 & 61,77 & 359,29 & 37,50 & 103,00 & 750,00 & Does not occurs \\
\hline LIJIC & 82,43 & 63,10 & 298,02 & 37,50 & 103,00 & 750,00 & Diagonal tension \\
\hline L1J2C & 90,81 & 103,84 & 184,55 & 37,50 & 103,00 & 750,00 & Diagonal tension/Shear \\
\hline LIJ3C & 95,76 & 109,48 & 197,44 & 37,50 & 103,00 & 750,00 & Diagonal tension/Shear \\
\hline
\end{tabular}

submitted to high stresses, even when satisfies the interstory drift limits from NBR 6118 in conventional modeling. To minimize uncertainties, it may be useful to carry out a complementary verification of the service limit state with modeling that includes the infill walls. The analysis of single-story one-bay infilled frames that simulates consecutive stories, following the method presented in Example 2, may provide important information related to the level of stresses in the walls. In the case of walls with openings, this analysis can be performed using the finite elements method, following Example 2 and the work of Silva [40].

\section{Acknowledgements}

The authors thank CNPq for research funding (Edital Universal).

\section{References}

[1] ALVARENGA, R.C. Análise teórico-experimental de estruturas compostas de pórticos de aço preenchidos com alvenaria de concreto celular autoclavado. 331p. Tese (Doutorado) Escola de Engenharia de São Carlos, Universidade de São Paulo, São Carlos, 2002.

[2] SANTOS, E.M. Influência da alvenaria no structural behaviorde edifícios altos de concreto armado. 132p. Dissertação (Mestrado) - Universidade Católica de Pernambuco, Recife, 2007.

[3] TANAKA, E.S. Influência da alvenaria dotada de aberturas na stiffnessglobal de um edifício. 90p. Dissertação (Mestrado) - Universidade Estadual de Campinas, Campinas, 2011.

[4] MADIA, F.C. Estudo de pórticos preenchidos com alvenaria. 142p. Dissertação (Mestrado) - Universidade Federal de São Carlos, São Carlos, 2012.

[5] ASTERIS, P.G.; ANTONIOU, S.T.; SOPHIANOPOULOS, D.S.; CHRYSOSTOMOU, C.Z. Mathematical Macromodeling of Infilled Frames: State of the Art. Journal of the Structural Engineering, v.137, n.12, p.1508-1517, 2011.

[6] CHRYSOSTOMOU, C.Z.; ASTERIS, P.G. On the in-plane properties and capacities of infilled frames. Engineering Structures, v.41, Aug, p.385-402, 2012.

[7] EL-DAKHAKHNI, W.W.; ELGAALY, M.; HAMID, A.A. ThreeStrut Model for Concrete Mansory-Infilled Steel Frames. Journal of the Structural Engineering, v.129, n.2, p.177-185, 2003.

[8] AMATO, G.; FOSSETTI, M.; CAVALERI, L.; PAPIA, M. An Updated Model of Equivalent Diagonal Strut for Infill Panels, Proc. Final Conference of Progetto ReLuis-DPC, Eurocode
8 Perspectives from the Italian Standpoint Workshop, Naples, 1-3 April 2009, pp. 119-128.

[9] DOUDOMIS, I.N. Improving Lateral Stiffness Estimation in the Diagonal Strut Model of Infilled Frames. Proceedings of the 14th World Conference on Earthquake Engineering, 2008, Beijing.

[10] CRISAFULLI, F.J.; CARR, A.J. Proposed Macro-Model for the Analysis of Infilled Frame Structures. Bulletin of the New Zealand Society for Earthquake Engineering, v.40, n.2, p.6977, 2007.

[11] UVA, G.; RAFFAELE, D.; PORCO, F.; FIORE, A. On the role of equivalent strut models in the seismic assessment of infilled RC buildings. Engineering Structures, v.42, p.83-94, 2012.

[12] DOUDOUMIS, I.N. Finite element modelling and investigation of the behaviour of elastic infilled frame under monotonic loading. Engineering Structures, v.29, p.1004-1024, 2007.

[13] MONDAL, G.; JAIN, S.K. Lateral stiffness of masonry infilled reinforced concrete $(R C)$ frames with central opening. Earthquake Spectra, v.24, n.3, p.701-723, 2008.

[14] ASTERIS, P.G. Lateral Stiffness of Brick Masonry Infilled Plane Frames. Journal of the Structural Engineering, v.129, n.8, p.1071-1079, 2003.

[15] GOSH, A.K.; ADSM, A.M. Finite Element Analysis of Infilled Frames. Journal of the Structural Engineering, v.128, n.7, p.881-889, 2002.

[16] MOHYEDDIN, A.; GOLDSWORTHY, H.M.; GAD, E.F. FE modelling of RC frames with masonry infill panels under in-plane and out-of-plane loading. Engineering Structures, v.51, p.73-87, 2013.

[17] STAVRIDIS, A.; SHING, P.B. Finite-Element Modeling of Nonlinear Behavior of Masonry-Infilled RC Frames. Journal of the Structural Engineering, v.136, n.3, p.285-296, 2010.

[18] BALOEVIC, G.; RADNIC, J.; HARAPIN, A. Numerical dynamic tests of masonry-infilled RC frames. Engineering Structures, v.50, p.43-55, 2013.

[19] KOUTROMANOS, I.; STAVIDRIS, A.; SHING, P.B.; WILLAM, K. Numerical modeling of masonry-infilled RC frames subjected to seismic loads. Computers and Structures, v.89, p.1026-1037, 2011.

[20] MEHRABI, A.B.; SHING, P.B.; SCHULLER, M.P.; NOLAND, J.L. Experimental Evaluation of Masonry-Infilled RC Frames. Journal of the Structural Engineering, v.122, n.3, p.228-237, 1996.

[21] DURRANI, A.J.; HAIDER, S. Seismic Response of R/C 
Frames with Unreinforced Masonry Infills. Proceedings of the 11th World Conference on Earthquake Engineering, 1996, Acapulco.

[22] FLANAGAN, R.D.; BENETT, R.M. In-Plane Behavior of Structural Clay Tile Infilled Frames. Journal of Structural Engineering, v.125, n.6, p.590-599, 1999.

[23] AL-CHAAR, G.; ISSA, M.; SWEENEY, S. Behavior of Masonry-Infilled Nonductile Reinforced Concrete Frames. Journal of Structural Engineering, v.128, n.8, p.1055-1063, 2002.

[24] ASTERIS, P.G.; KAKALETSI, D.J.; CHRYSOSTOMOU, C.Z.; SMYROU, E.E. Failure Modes of In-filled Frames. Electronic Journal of Structural Engineering, v.11, n.1, p.1120, 2011.

[25] TASNIMI, A.A.; MOHEBKHAH, A. Investigation on the behavior of brick-infilled steel frames with openings, experimental and analytical approaches. Engineering Structures, v.33, p.968-980, 2011.

[26] LIU, H.; MANESH, P. Concrete masonry infilled steel frames subjected to combined in-plane lateral and axial loading - An experimental study. Engineering Structures, v.52, p.331-339, 2013.

[27] FEDERAL EMERGENCY MANAGEMENT AGENCY. FEMA 306: Evaluation of earthquake damage concrete and masonry wall buildings, Basic Procedures Manual, Washington, DC, 1998.

[28] FEDERAL EMERGENCY MANAGEMENT AGENCY. FEMA 274: NEHRP commentary on the guidelines for the seismic rehabilitation of buildings, BSSC Seismic Rehabilitation Project, Washington, DC, 1997.

[29] FEDERAL EMERGENCY MANAGEMENT AGENCY. FEMA 356: Prestandard and commentary for seismic rehabilitation of buildings, Chapter 7: Masonry, Washington, DC, 2000

[30] ABNT. ASSOCIAÇÃO BRASILEIRA DE NORMAS TÉCNICAS. NBR 6118: Projeto de estruturas de concreto. Procedimento. Rio de Janeiro, ABNT, 2014.

[31] ABNT. ASSOCIAÇÃO BRASILEIRA DE NORMAS TÉCNICAS. NBR 15575-2: Edificações habitacionais - Desempenho - Parte 2: Sistemas Estruturais. Rio de Janeiro, 2013.

[32] MAINSTONE, R.J. Supplementary note on the stiffness and strengths of infilled frames. Building Research Station, Garston, UK, 1974.

[33] AL-CHAAR, G. Evaluating Strength and Stiffness of Unreinforced Masonry Infill Structures, ERDC/CERL TR-02-1, US Army Corps of Engineers, Construction Engineering Research Laboratory, 2002.

[34] HENDRY, A. Structural Brickwork. MacMillan, London, 1981.

[35] LIAUW, T.C.; KWAN, K.H. Nonlinear behavior of non-integral infilled frames. Computers and Structures, v.18, n.3, p.551560,1984

[36] DECANINI, L.D.; FANTIN, G.E. Modelos simplificados de la mampostería incluida en porticos. Caracteristicas de stiffnessy resistencia lateral en estado limite. Jornadas Argentinas de Ingeniería Estructural, v.2, Buenos Aires, Argentina, p.817-836, 1987.

[37] PAULAY, T.; PRIESTLEY, M.J.N. Seismic design of reinforced concrete and masonry buildings. Wiley, New York, 744, 1992.

[38] DURRANI, A.J.; LUO, Y.H. Seismic retrofit of flat-slab build- ings with masonry infills. Proceedings from the NCEER Workshop on Seismic Response of Masonry Infills, National Center for Engineering Earthquake, Buffalo, N.Y., 1994.

[39] ABNT. ASSOCIAÇÃO BRASILEIRA DE NORMAS TÉCNICAS. NBR 15812-1: Alvenaria Estrutural - Blocos Cerâmicos. Parte 1: Projeto. Rio de Janeiro, ABNT, 2010.

[40] SILVA, L. R. Modelingde pórticos de concreto armado preenchidos com a consideração de aberturas nos painéis de alvenaria. 139p. Dissertação (Mestrado em Engenharia Civil) - Universidade Federal de Santa Maria, Santa Maria, 2014.

[41] SILVA, L.R.; ALVA, G.M.S.; KAMINSKI JUNIOR, J.. Avaliação e aprimoramento do modelo de diagonal equivalent strutna structural analysis de pórticos de concreto preenchidos com alvenaria. In: $55^{\circ}$ Congresso Brasileiro do Concreto, Gramado, 2013, Anais... IBRACON, 2013. 